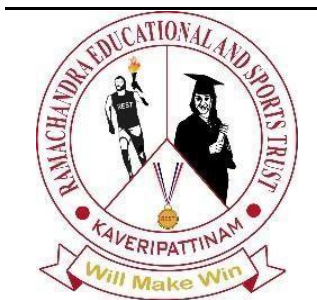

REST Journal on Emerging trends in Modelling andManufacturing

Vol: 7(2), 2021

REST Publisher

ISSN: 2455-4537

Website: www.restpublisher.com/journals/jemm

\title{
A Study to Assess the Relationship between Emotional Intelligence (EI) and Adjustment Level
}

Ms. Sabeena M T P

Lecturer, Mental Health Nursing Department, Father Muller College of Nursing, Mangalore

Email: sabeena.mtp@gmail.com

\section{Background and objectives}

All of us have different personalities, different needs and different ways of showing our emotions. Navigating through this all takes cleverness - especially if we hope to succeed in life. This is where emotional intelligence becomes important.Emotional intelligence has been defined as the ability to adaptively recognize, understand and mange and harness emotions both in self and others and to use emotions to facilitate cognitive processing. It is a skill which involves three processes that are perception (or the ability to consciously recognize our emotions), understanding (integrating what is in our thought), and regulation (lead and manage effectively both positive and negative emotions).

EI can be described as a set of emotional and social skills that collectively establish how well we:

$\bullet$

- $\quad$ Develop and maintain social relationships, how we empathies and work with other people.

- $\quad$ Cope with challenges, recovering quickly from stress and negative emotions.

- Use emotional information in an effective and meaningful way in other words tuning in to subtle signals that the body tells us.

Adolescence is a crucial period in which young people search for identity and meaning in life and the important aspects are their emotions and self-esteem. Goleman has cited that there is a worldwide trend for the present generation to be more troubled emotionally than others; more lonely and depressed; more angry and unruly; more impulsive and angry; and more nervous and prone to worry.Emotional intelligence can determine the quality of our relationship with our self and others. Whether we are students, teachers or managers or are in the clinical area, EI influences our stress level, our ability to perform, and our effectiveness when working with others. The main purpose of this study was to find out the relationship between emotional intelligence and adjustment problems among $1^{\text {st }}$ year B.Sc Nursing students of a selected college of nursing.

\section{Objectives of the study}

1. Identify the level of emotional intelligence of the students using a rating scale.

2. Assess the adjustment level of students using rating scale.

3. Identify the relationship between emotional intelligence and adjustment level of students.

4. Find out the association of emotional intelligence score and adjustment level with selected baseline variables (educational level of parents, occupation of parents, number of siblings, birth order and family income per month).

\section{Method}

A descriptive correlational survey design was used for the study. Convenience sampling technique was used to select the sample. The sample for the present study consisted of 75 B. Sc. nursing students. Data was collected using EI rating scale and adjustment rating scale. Data was analyzed using descriptive and inferential statistics.

\section{Result}

There is a low negative correlation between emotional intelligence and adjustment level. The obtained ' $r$ ' value (-0.01261) is statistically significant at 0.05 level of significance. It can be inferred that as emotional level improves adjustment also improves. Statistically there is no significant association between mean emotional intelligence score and selected baseline variables at 0.05 level of significance. Statistically there is no significant association between mean adjustment problem score and selected baseline variables at 0.05 level of significance. However, there was a statistically significant association between adjustment level score and mother's occupation. The obtained $\chi^{2}$ value (4.60) is more than the table value $(3.84$, $\mathrm{p} \leq 0.05)$.

\section{Interpretation and conclusion}

There is a low negative correlation between emotional intelligence and adjustment level. The obtained ' $r$ ' value (-0.01261) is statistically significant at 0.05 level of significance. Therefore, the null hypothesis is rejected and research hypothesis is accepted. It can be inferred that as emotional level improves adjustment also improves. 
Keywords: Emotional intelligence; Adjustment level; Nursing Students.

\section{Introduction}

Studies have revealed that people with average IQ, more often than not, outperform those with higher IQ. The reason is Emotional Intelligence. ${ }^{1}$ All of us have different personalities, different needs and different ways of showing our emotions. Navigating through this all takes cleverness - especially if we hope to succeed in life. This is where emotional intelligence become important. ${ }^{2} \mathrm{As}$ we venture into the millennium, the word emotion has emerged with a new meaning. The word emotional means "markedly aroused or agitated in feeling or sensibilities." 3 A person is said to be emotionally intelligent when he feels proper emotions in a proper situation and express it in proper quantity. It is estimated that worldwide there are 1.2 million adolescents. ${ }^{5}$ Adolescence period is a crucial period in which young people search for identity and meaning in life and the important aspects are their emotions and self-esteem. Goleman has cited that there is a worldwide trend for the present generation to be more troubled emotionally than others; more lonely and depressed; more angry and unruly; more impulsive and angry; and more nervous and prone to worry. ${ }^{3}$ Adolescent students should be regularly assessed for their Emotional Intelligence as it affects the self esteem and other variables of individuals. Educational interventions should be included in curriculum to manage emotional immaturity among adolescents. ${ }^{3}$ Adolescents is the developmental period of transition between childhood and adulthood, it involve biological, cognitive and socio emotional changes. These changes make a young person's vision more complex, well organised and consistent picture. They are more likely to employ complex, abstract and psychological self characteristics. ${ }^{6}$ Emotional intelligence (EI) has been defined as the ability to adaptively recognise, understand and manage and harness emotions both in self and others and to use emotions to facilitate cognitive processing. It is a skill which involves three processes that are perception (or the ability to consciously recognise our emotions), understanding (integrating what is in our thought), and regulation (lead and manage effectively both positive and negative emotions).Emotional intelligence is considered as a critical component of a nurse's characteristics traits which is known as a significant predictor of a person's job performance and life success. ${ }^{7}$ Emotional intelligence is the aptitude to perceive, express and logically process information provided by the emotions in the self and others. EI provides the foundation for the development of many competencies that help people perform more effectively. A person's EI can influence individuals, teams and organisations. ${ }^{1} \mathrm{~A}$ study was conducted on the topic: emotional intelligence. Its more than IQ. It revealed that Emotional intelligence (EI) can determine the quality of our relationship with ourselves and others. Whether we are students, teachers, or managers or are in the clinical arena, EI influences our stress level, our ability to perform, and our effectiveness when working with others. ${ }^{8}$ The future of nursing, leading change and advancing healthcare, challenges the profession of nursing to assume leadership of interdisciplinary healthcare teams. Leading these teams requires cognitive ability to manage highly charged and emotional work. Emotional intelligence is a characteristic necessary to process emotional information for creative problem solving. In addition, emerging evidence indicate that there may be an association of nurse's EI and quality patient care. ${ }^{9}$

EI can be described as a set of emotional and social skills that collectively establish how well we:

$\bullet$

- $\quad$ Develop and maintain social relationships, how we empathies and work with other people.

- $\quad$ Cope with challenges, recovering quickly from stress and negative emotions.

- Use emotional information in an effective and meaningful way in other words tuning in to subtle signals that the body tells us. ${ }^{1}$

An article regarding EI and its role in recruitment of nursing students has explained about the concept of EI and how it can be used in the recruitment and development of nursing students. The links between EI and the qualities of caring and compassions are examined. The ethical difficulties surrounding the use of emotional intelligence tests are explored and the values of using a variety of recruitment methods are emphasized. The article suggested that emotional intelligence is an ability which may be developed through nurse education programme, even if not fully present at interview. ${ }^{10} \mathrm{~A}$ research study aimed at analysing the correlation of self compassion and emotional intelligence of nursing students. Results indicated that there is a correlation between self compassion and EI which include the individual perceiving one's emotions and using the knowledge one gained from them to function, while directing thoughts, actions and professional applications. It has positive contribution to the features of nurse with developed self compassion. ${ }^{11}$ Emotional training adds an important aspect of education in that it would prepare learners to better cope with environmental demands and increase their ability to function and succeed in their life. ${ }^{1}$

\section{Research approach}

\section{Materials and Method}

Research approach is a basic procedure for conduction of the research study. The selection of the research approach depends on the purpose of the study. In view of the nature of problem selected for the study and objectives to be accomplished quantitative non experimental descriptive survey method was found to be best method for this study.

\section{Research design}

The research design is the master plan specifying the methods and procedures for collecting and analysing the needed information in a research study. ${ }^{9}$ The research design adopted for the present study was a descriptive correlational survey design. The study intended to find out the correlation between emotional intelligence and adjustment level of $1^{\text {st }}$ year $\mathrm{B}$. Sc. nursing students. 


\section{Results}

In this study, the data was analysed based on the objectives and hypothesis of the study using descriptive and inferential statistics.

\section{Hypotheses}

All the hypotheses will be tested at 0.05 level of significance.

$\mathrm{H}_{1}$ : There will be a significant relationship between emotional intelligence and adjustment level of $1^{\text {st }}$ year B. Sc. nursing students of a selected nursing college.

$\mathrm{H}_{2}$ : There will be significant association between mean emotional intelligence score of students with selected baseline variables.

$\mathrm{H}_{3}$ : There will be significant association between mean adjustment level score of students with selected baseline variables.

\section{Organisation of the findings}

The data collected from $1^{\text {st }}$ year B. Sc. nursing students regarding EI and adjustment level are organised, analysed, and presented under the following headings:

Section I: Description of demographic proforma.

Section II: Description of Emotional Intelligence of $1^{\text {st }}$ year B. Sc. nursing students.

Section III: Description of adjustment level of $1^{\text {st }}$ year B. Sc. nursing students.

Section IV: Relationship between EI score and adjustment level score of $1^{\text {st }}$ year B. Sc. nursing students.

Section V: Association of EI score and adjustment level score of $1^{\text {st }}$ year B. Sc. nursing students with their demographic variables.

\section{Section I: Demographic proforma}

This section deals with the data pertaining to the demographic proforma of the $1^{\text {st }}$ year B. Sc. nursing students. The demographic variables are analysed using descriptive statistics. The data obtained from 75 students was analysed using descriptive statistics and is presented in terms of frequency and percentage.

Table 1.Frequency and percentage distribution of sample according to selected demographic variablesn=75

\begin{tabular}{|c|c|c|c|}
\hline Sl. No. & Variable & Frequency & Percentage \\
\hline \multirow[t]{6}{*}{1.} & Fathers education & & \\
\hline & No formal education & 4 & 5.3 \\
\hline & Primary & 9 & 12.0 \\
\hline & Higher primary & 42 & 56.0 \\
\hline & PUC & 19 & 25.3 \\
\hline & Any other & 1 & 1.4 \\
\hline \multirow[t]{6}{*}{2.} & Mother's education & & \\
\hline & No formal education & 2 & 2.7 \\
\hline & Primary & 8 & 10.6 \\
\hline & Higher primary & 42 & 56.0 \\
\hline & PUC & 23 & 30.7 \\
\hline & Any other & 0 & 0.0 \\
\hline \multirow[t]{6}{*}{3.} & Father's occupation & & \\
\hline & Farmer & 29 & 38.7 \\
\hline & Daily wage worker & 15 & 20.0 \\
\hline & Business & 15 & 20.0 \\
\hline & Professional & 13 & 17.3 \\
\hline & Any other & 3 & 4.0 \\
\hline
\end{tabular}

Table 1.Frequency and percentage distribution of sample according to selected demographic variablesn=75

\begin{tabular}{|c|l|c|c|}
\hline Sl. No & \multicolumn{1}{|c|}{ Variable } & Frequency & Percentage \\
\hline 4. & Mother's occupation & 63 & \\
& Home maker & 8 & 84.0 \\
& Daily wage worker & 1 & 10.7 \\
& Professional & 3 & 1.3 \\
& Any other & & 4.0 \\
\hline 5. & Monthly income of parents in rupees & 40 & \\
& $\leq 10000$ & 22 & 53.3 \\
& $10001-150000$ & 13 & 29.3 \\
& $\geq 15000$ & & 17.4 \\
\hline
\end{tabular}




\begin{tabular}{|c|l|c|c|}
\hline 6. & Number of siblings & 38 & 50.6 \\
& 1 & 26 & 34.7 \\
& 2 & 11 & 14.7 \\
\hline 7. & 3 or more & 33 & \\
& Birth order & 31 & 41.3 \\
& $1^{\text {st }}$ & 11 & 44.0 \\
& $2^{\text {nd }}$ & 34.7 \\
\hline
\end{tabular}

Data presented in the Table1 and Figure 3 shows that more than half $(56 \%)$ of the fathers had completed higher primary education, few of the fathers (5.33\%) had no formal education, (12\%) had primary education, $25 \%$ had studied up to PUC or above and $1.33 \%$ finished some other education courses.

Figure 3: Bar diagram showing the distribution of sample according to their father's educational status Figure 4: Cylindrical diagram showing the distribution of sample according to their mother's educational status Data presented in the Table 1 and Figure 4 shows that 2.66\% of the mothers had no formal education, $10.66 \%$ had completed primary education, $56 \%$ had higher primary education, and $30.66 \%$ had studied up to PUC or above.

Figure 5: Cone diagram showing the distribution of sample according to father's occupation Data presented in the Table1 and Figure 5 shows that 38.66\% were farmers, 20\% were daily wage workers, 20\% were having business, $17.33 \%$ were professionals and $3 \%$ were doing some other jobs.

Figure 6: Pyramid diagram showing the distribution of sample according to their mother's occupation Data presented in the Table 1 and Figure 6 shows that most of the mothers (84\%) were homemakers, $10.66 \%$ were daily wage workers, $1.33 \%$ were professionals and $4 \%$ were doing some other jobs.

Figure 7: Pie diagram showing the distribution of sample according to monthly income of parents (in rupees) It is evident from the data presented in Table 1 and Figure 7 that more than half (53.33\%) of the sample had a family income of rupees $\leq$ Rs. $10000,29.33 \%$ had Rs. $10001-15000$ and $17.33 \%$ had an income of above Rs. 15001 per month.It is evident from Table 1 and figure 8 that $50.66 \%$ had one sibling, $34.66 \%$ had two siblings and $14.66 \%$ had three or more siblings.

Figure 8: Pie diagram showing the distribution of samples according to the number of siblings

Figure 9: Bar diagram showing the distribution of sample according to their birth order

Data presented in Table 1 and Figure 9 shows that $41.33 \%$ were $1^{\text {st }}$ born, $44 \%$ were $2^{\text {nd }}$ born and $14.66 \%$ were in $3^{\text {rd }}$ or more than $3^{\text {rd }}$ in birth order.

\section{Section II: Description of Emotional Intelligence of $1^{\text {st }}$ year B. Sc. nursing students}

Emotional intelligence of nursing students was assessed using rating scale and was analysed using descriptive statistics which is represented in Table 2.It is evident from Table 2 and Figure 10 that majority (84\%) of the sample had high emotional intelligence and only $14 \%$ had moderate emotional intelligence and none of them had low emotional intelligence. The mean score was $130 \pm 10.10$.

Table 2.Range Frequency, percentage, Mean, and standard deviation of EI score of the samplen $=\mathbf{7 5}$

\begin{tabular}{|c|c|c|c|c|c|c|}
\hline $\begin{array}{l}\text { Level of } \\
\text { intelligence }\end{array}$ & emotional & Score range & Frequency & Percentage & $\begin{array}{c}\text { Mean } \\
\text { score }\end{array}$ & SD \\
\hline $\begin{array}{l}\text { High } \\
\text { intelligence }\end{array}$ & emotional & $121-160(76-100 \%)$ & 63 & 84 & \multirow[t]{2}{*}{130} & \multirow[t]{2}{*}{10.10} \\
\hline $\begin{array}{l}\text { Moderate } \\
\text { intelligence }\end{array}$ & emotional & $80-120(50 \%-75 \%)$ & 12 & 16 & & \\
\hline
\end{tabular}

Maximum

score:

Adjustment problems of nursing students were assessed using rating scale and were analysed using descriptive statistics which is represented in Table 3.

Table 3.Range Frequency, percentage, Mean, and standard deviation of adjustment problem of the samplen=75

\begin{tabular}{|l|l|c|c|c|c|}
\hline $\begin{array}{l}\text { Level of } \\
\text { adjustment }\end{array}$ & \multicolumn{1}{|c|}{ Score range } & Frequency & Percentage & $\begin{array}{c}\text { Mean } \\
\text { score }\end{array}$ & SD \\
\cline { 1 - 3 } Poor & $1-61(0-50 \%)$ & 3 & 4 & 75.50 & 9.70 \\
\cline { 1 - 3 } Satisfactory & $62-93(50 \%-75 \%)$ & 70 & 93.3 & & \\
\cline { 1 - 3 } Good & $94-124(76 \%-100 \%)$ & 2 & 2.7 & & \\
\hline
\end{tabular}

Maximum score: 124 
Figure 11: Cone diagram showing the adjustment of the sample

It is evident from Table 3 and Figure 11 that only $4 \%$ had poor adjustment level and most of them (93.3\%) had satisfactory adjustment level. The mean score was $75.5 \pm 9.70$.

Section IV: Relationship between EI score and adjustment level score of $1^{\text {st }}$ year B. Sc. nursing students

In order to find the correlation between EI and adjustment level of the sample the following null hypothesis was formulated:

Ho: $\quad$ There will be no significant relationship between emotional intelligence and adjustment level of $1^{\text {st }}$ year B. Sc. nursing students at 0.05 level of significance.

Table 4. Karl Pearson correlation coefficient to find out the correlation between EI and adjustment problemn=75

\begin{tabular}{|l|c|c|c|l|}
\hline Variables & Mean score & SD & 'r' value & Inference \\
\hline EI & 130 & 10.10 & -0.01261 & $\begin{array}{l}\text { Low negative } \\
\text { correlation }\end{array}$ \\
\cline { 1 - 3 } Adjustment level & 75.5 & 9.70 & & \\
\hline
\end{tabular}

It is evident from Table 4 show that there is a low negative correlation between emotional intelligence and adjustment level. The obtained ' $r$ ' value

$(-0.01261)$ is statistically significant at 0.05 level of significance. Therefore the null hypothesis is rejected and research hypothesis is accepted. It can be inferred that as emotional level improves adjustment also improves.

Section V: Association of EI score and adjustment level score of $1^{\text {st }}$ year $B$. Sc. nursing students with their demographic variables

Chi square test was used to find out the association between score of $1^{\text {st }}$ year B. Sc. Nursing students towards EI and adjustment level and their selected demographic variable, and the following null hypothesis was stated:

$\mathrm{H}_{02}$ : $\quad$ There will be no significant association between emotional intelligence score of students with selected baseline variables at 0.05 level of significance.

Table 5.Chi-square test to find out the association between EI score of $1^{\text {st }}$ year B. Sc. nursing students with their selected baseline variablesn=75

\begin{tabular}{|c|c|c|c|c|c|}
\hline \multirow[t]{2}{*}{ Sl. No. } & \multirow[t]{2}{*}{ Variable } & \multicolumn{2}{|c|}{ EI Score } & \multirow[t]{2}{*}{$\chi^{2}$ value } & \multirow[t]{2}{*}{ Inference } \\
\hline & & $\leq$ Mean & $\geq$ Mean & & \\
\hline 1. & $\begin{array}{l}\text { Father's education } \\
\leq \text { Primary } \\
\text { Higher primary } \\
\text { PUC }\end{array}$ & $\begin{array}{c}8 \\
18 \\
7\end{array}$ & $\begin{array}{c}5 \\
24 \\
13\end{array}$ & 2.271 & $\begin{array}{l}\text { Not } \\
\text { significant }\end{array}$ \\
\hline 2. & $\begin{array}{l}\text { Mother's education } \\
\leq \text { Primary } \\
\text { Higher primary/ PUC }\end{array}$ & $\begin{array}{c}7 \\
25\end{array}$ & $\begin{array}{c}3 \\
40\end{array}$ & 3.52 & $\begin{array}{l}\text { Not } \\
\text { significant }\end{array}$ \\
\hline 3. & $\begin{array}{l}\text { Father's occupation } \\
\text { Farmer } \\
\text { Daily wager/business/professional }\end{array}$ & $\begin{array}{l}18 \\
18\end{array}$ & $\begin{array}{l}11 \\
28\end{array}$ & 3.74 & $\begin{array}{l}\text { Not } \\
\text { significant }\end{array}$ \\
\hline 4. & $\begin{array}{l}\text { Mothers occupation } \\
\text { Homemaker } \\
\text { Daily wage worker/others }\end{array}$ & $\begin{array}{c}30 \\
3\end{array}$ & $\begin{array}{c}33 \\
9\end{array}$ & 1.27 & $\begin{array}{l}\text { Not } \\
\text { significant }\end{array}$ \\
\hline 5. & $\begin{array}{l}\text { Monthly income of parents (Rupees) } \\
\leq 10000 \\
\geq 10001\end{array}$ & $\begin{array}{l}18 \\
17\end{array}$ & $\begin{array}{l}22 \\
18\end{array}$ & 0.09 & $\begin{array}{l}\text { Not } \\
\text { significant }\end{array}$ \\
\hline 6. & $\begin{array}{l}\text { Number of siblings } \\
\mathbf{1} \\
\geq 2\end{array}$ & $\begin{array}{l}16 \\
17\end{array}$ & $\begin{array}{l}22 \\
20\end{array}$ & 0.11 & $\begin{array}{l}\text { Not } \\
\text { significant }\end{array}$ \\
\hline 7. & $\begin{array}{l}\text { Birth order of the sample } \\
1^{\text {st }} \\
\geq 2^{\text {nd }}\end{array}$ & $\begin{array}{l}16 \\
18\end{array}$ & $\begin{array}{l}15 \\
26\end{array}$ & 0.84 & $\begin{array}{l}\text { Not } \\
\text { significant }\end{array}$ \\
\hline
\end{tabular}

Data presented in Table 5 shows that statistically there is no significant association between mean emotional intelligence score and selected baseline variables at 0.05 level of significance. Therefore the null hypothesis is retained.

$\mathrm{H}_{03}$ : There will be no significant association between adjustment problems of students with selected baseline variables at 0.05 level of significance. 
Table 6.Chi-square test to find out the association between adjustment level score of $1^{\text {st }}$ year B. Sc. Nursing students with their selected baseline variablesn=75

\begin{tabular}{|c|c|c|c|c|c|}
\hline \multirow[t]{2}{*}{ Sl. No. } & \multirow[t]{2}{*}{ Variable } & \multicolumn{2}{|c|}{ Adjustment score } & \multirow[t]{2}{*}{$\chi^{2}$ value } & \multirow[t]{2}{*}{ Inference } \\
\hline & & $\leq$ Mean & $\geq$ Mean & & \\
\hline 1. & $\begin{array}{l}\text { Father's education } \\
\leq \text { Primary } \\
\text { Higher primary } \\
\text { PUC }\end{array}$ & $\begin{array}{c}7 \\
23 \\
9\end{array}$ & $\begin{array}{c}6 \\
19 \\
11\end{array}$ & 0.579 & $\begin{array}{l}\text { Not } \\
\text { significant }\end{array}$ \\
\hline 2. & $\begin{array}{l}\text { Mother's education } \\
\leq \text { Primary } \\
\text { Higher primary/ PUC }\end{array}$ & $\begin{array}{c}5 \\
35\end{array}$ & $\begin{array}{c}5 \\
30\end{array}$ & 0.0515 & $\begin{array}{l}\text { Not } \\
\text { significant }\end{array}$ \\
\hline 3. & $\begin{array}{l}\text { Father's occupation } \\
\text { Farmer } \\
\text { Daily wager/business/professional }\end{array}$ & $\begin{array}{l}16 \\
25\end{array}$ & $\begin{array}{l}13 \\
21\end{array}$ & 0.004 & $\begin{array}{l}\text { Not } \\
\text { significant }\end{array}$ \\
\hline 4. & $\begin{array}{l}\text { Mothers occupation } \\
\text { Homemaker } \\
\text { Daily wage worker/others }\end{array}$ & $\begin{array}{c}37 \\
3\end{array}$ & $\begin{array}{c}26 \\
9\end{array}$ & 4.60 & Significant \\
\hline 5. & $\begin{array}{l}\text { Monthly income of parents (Rupees) } \\
\leq 10000 \\
\geq 10001\end{array}$ & $\begin{array}{l}23 \\
17\end{array}$ & $\begin{array}{l}17 \\
18\end{array}$ & 0.59 & $\begin{array}{l}\text { Not } \\
\text { significant }\end{array}$ \\
\hline 6. & $\begin{array}{l}\text { Number of siblings } \\
1 \\
\geq 2\end{array}$ & $\begin{array}{l}22 \\
18 \\
\end{array}$ & $\begin{array}{l}16 \\
19 \\
\end{array}$ & 0.643 & $\begin{array}{l}\text { Not } \\
\text { significant }\end{array}$ \\
\hline 7. & $\begin{array}{l}\text { Birth order of the sample } \\
1^{\text {st }} \\
\geq 2^{\text {nd }}\end{array}$ & $\begin{array}{l}17 \\
25\end{array}$ & $\begin{array}{l}14 \\
19\end{array}$ & 0.028 & $\begin{array}{l}\text { Not } \\
\text { significant }\end{array}$ \\
\hline
\end{tabular}

$\chi^{2}$ value at df $1=3.384 \mathrm{p} \leq 0.05$

Data presented in Table 6 shows that statistically there is no significant association between mean adjustment problem score and selected baseline variables at 0.05 level of significance. Therefore the null hypothesis is retained. However there was a statistically significant association between adjustment level score and mother's occupation. The obtained $\chi^{2}$ value is more than the table value $(3.84, \mathrm{p} \leq 0.05)$.

There is a low negative correlation between emotional intelligence and adjustment level. The obtained ' $r$ ' value (-0.01261) is statistically significant at 0.05 level of significance. It can be inferred that as emotional level improves adjustment also improves. Statistically there is no significant association between mean emotional intelligence score and selected baseline variables at 0.05 level of significance. Statistically there is no significant association between mean adjustment problem score and selected baseline variables at 0.05 level of significance. However, there was a statistically significant association between adjustment level score and mother's occupation. The obtained $\chi^{2}$ value (4.60) is more than the table value (3.84, $\mathrm{p} \leq 0.05)$.

\section{Interpretation and conclusion}

There is a low negative correlation between emotional intelligence and adjustment level. The obtained ' $r$ ' value (-0.01261) is statistically significant at 0.05 level of significance. Therefore the null hypothesis is rejected and research hypothesis is accepted. It can be inferred that as emotional level improves adjustment also improves.

\section{Discussion}

This chapter presents the major findings of this study and discuss them in relation to similar studies conducted by other researchers. The aim of this study was to assess the relationship between Emotional Intelligence and adjustment level of $1^{\text {st }}$ year B. Sc. nursing students. Data collection and analysis was carried out based on the objectives of the study.

\section{Objectives of the study}

1. Identify the level of emotional intelligence of the students using a rating scale.

2. Assess the adjustment level of students using rating scale.

3. Identify the relationship between emotional intelligence and adjustment level of students.

4. Find out the association of emotional intelligence score and adjustment level with selected baseline variables (educational level of parents, occupation of parents, number of siblings, birth order and family income per month).

Major findings of the study

Section I: Sample characteristics

1. Most of the $1^{\text {st }}$ year students' fathers $(56 \%)$ had studied up to higher primary, $25.33 \%$ were PUC.

2. Most of the $1^{\text {st }}$ year students' (56\%) mothers' education was higher primary, $30.7 \%$ were PUC or above. 
3. Majority of the fathers (38.66\%) were working as farmers. Daily wage workers and business men are in equal proportion $(20 \%)$ and only $17.33 \%$ were professionals.

4. Almost all (84\%) mothers were home makers, $10.66 \%$ were doing daily wage works, $1.33 \%$ were professionals and $4 \%$ were doing other works.

5. More than half $(53.33 \%)$ of the students had monthly family income of less than or equal to $10,000,29.33 \%$ had Rs. $10,001-15000$ and $13 \%$ had income above 15,001 .

6. About half of the students (50.6\%) were having only one sibling, $34.66 \%$ had two and the remaining (14.66\%) students were having three or more siblings.

7. With regard to birth order $44 \%$ students were standing in the $2^{\text {nd }}$ ordinal status, where as 41.335 were $1^{\text {st }}$ born. Very few students $(14.66 \%)$ were in $3^{\text {rd }}$ or more in birth order.

\section{Section II: Emotional intelligence and adjustment level of the sample}

Most of them (84\%) had high emotional intelligence and 16\% had moderate emotional intelligence. With regard to adjustment level only $4 \%$ had poor adjustment and $93.3 \%$ had satisfactory adjustment.

\section{Section III: Correlation between Emotional Intelligence and adjustment level of $1^{\text {st }}$ year B. Sc. nursing students}

Correlation coefficient ' $r$ ' test was computed to find out the relationship between emotional adjustment and adjustment level and the calculated ' $r$ ' value

(-0.0126) showed a very low negative correlation.

The obtained ' $r$ ' value $(-0.01261)$ is statistically significant at 0.05 level of significance. It can be inferred that as emotional level improves adjustment also improves.

The findings of the present study are supported by findings of other researchers wherein it is shown that there is a relationship between emotional intelligence and adjustment level of students. One study showed the significant relationship between EI and adjustment among students. ${ }^{12}$

A study was conducted a study on Emotional Intelligence ability and grade point average in nursing students in order to explore the relationship between measured emotional intelligence ability and grade point average (GPA) of first year nursing students. The findings showed for some relationship between GPA and measured emotional intelligence ability, but also demonstrated lower than average range scores in several emotional intelligence scores. ${ }^{13}$

A study was conducted to find out the relationship of EI with adjustment, stress and achievement among 200 male and female senior secondary students from rural and urban area schools located in Delhi region using standardized test by descriptive survey method. The study showed that there was a correlation between emotional intelligence and academic intelligence, emotional intelligence and stress, EI and adjustment (home, health, social and economical). ${ }^{14}$

\section{Section IV: Association between adjustment score and selected demographic variables}

To find the association between the mean score of EI and adjustment level with selected demographic variables Chi-square test was used. There was no significant association between EI and selected demographic variables as well as association between adjustment level and demographic variables except for mother's occupation and adjustment level. The obtained value (4.60) is higher than the table value $(3.84, \mathrm{p} \leq 0.05)$. The findings of the present study are supported by findings of other researchers. A study was conducted on personal, family and academic factors towards Emotional Intelligence. This study revealed that there is no correlation between parent's employment and parent's educational level with EI. The same study proved that academic performance was not correlated with EI. ${ }^{15} \mathrm{An}$ article named "comparing adolescent only children with those who have siblings on academic related outcomes and psychosocial adjustment" revealed that there is no impact of number of siblings or order of delivery on academic outcomes and psychosocial adjustment. ${ }^{16}$

\section{Conclusion}

This chapter deals with the major findings of the study, nursing implications, limitations of the study, suggestions, and recommendations based on the study.Emotional intelligence theory provides a view about predicting effective factors in people's lives whether in education or profession. According to earlier studies, people who have higher emotional skills are more successful in many of life aspects.eg: reaction to stress and controlling stress situations, managing adjustment problems, etc. ${ }^{17}$ The conclusions drawn based on the findings of the study are:

\section{Major findings of the study}

1. Most of the $1^{\text {st }}$ year students (56\%) father's education was higher primary.

2. Most of the mother's (56\%) education was higher primary.

3. With regard to occupation, $38.66 \%$ fathers were working as farmers.

4. Almost all (84\%) of mothers were home makers.

5. More than half (53.33\%) of the students' family had monthly income of less than or equal to Rs. $10,000$.

6. About half of the students (50.6\%) were having only one sibling, $34.66 \%$ had two and the remaining (14.66\%) students were having three or more siblings.

7. Majority (44\%) of the students were $2^{\text {nd }}$ birth order $41.33 \%$ were firstborn.

Most of the sample (84\%) had high EI and only $3 \%$ had poor adjustment. A very low negative correlation was found between EI and adjustment level. There was no association between the EI and adjustment level with selected demographic variables. 


\section{Implications of the study}

The present study was conducted to find out the relationship between emotional intelligence and adjustment level of students. The study provided useful information regarding the EI and adjustment level of students and it showed that when EI is good adjustment problems decreases. Hence, the findings of the present study have implications for nursing in all these areas.

\section{Nursing education}

The curriculum of Indian nursing schools and colleges gives prime importance to the technical aspects of care and academic performance of the students rather than to the psychological aspects. The concept of EI should be given adequate weightage in the nursing curriculum. An effective guidance and education based on EI can improve the adjustment level of the students.

\section{Nursing practice}

Both at the undergraduate and postgraduate level, the nursing students should be trained to identify their EI level which will help them to have a better adjustment level in the clinical area. An emotionally stable person will be able to handle the problems effectively and also help the patients in handling their problems.

\section{Nursing administrators}

A nurse administrator should take measures to promote health of the students. Counselling facility should be available for the students as well as for patients. Early identification of adjustment problem in the college as well as in the clinical area is important. In service education programmes such as stress management, problem solving skills etc. should provided.

\section{Nursing research}

One of the aims of nursing research is to expand and broaden the scope of nursing. Emphasis on research and clinical studies is needed to improve the quality of nursing care. Nurses should conduct projects and researches which will give knowledge regarding new concept like EI which in turn will help to improve their adjustment level.

\section{Limitations of the study}

1. The sample was selected from only one college at Mangalore, which limits the generalization of the findings.

2. The rating scales prepared by the investigator for measuring adjustment level and EI was used for data collection which restricted the amount of information that can be obtained from the respondents.

3. No intervention was conducted to improve the adjustment level.

\section{Suggestions}

1. Health professionals can conduct planned teaching programs for nursing students regarding adjustment problems and ways to improve their EI.

2. Group and individual counselling sessions and education can be conducted to identify the students who have adjustment problems and give additional care to improve their EI.

\section{Recommendations}

Onthebasis of study the following recommendations have been made:

1. The study can be replicated on a larger sample for generalizing the findings.

2. The present study can be used as a baseline to plan for awareness program for nursing students regarding their adjustment problems.

3. Replication of the same study can be done on other population segments such as school or college students.

4. A comparative study can be conducted between the degree students and nursing students.

\section{Summary}

This chapter has dealt with the conclusions drawn based on the findings of the study, nursing implications, limitations, suggestions and recommendations. The experience of the investigator during the study helped to give suggestions and recommendations for further study.

\section{References}

1. Nadesa RA. How good is your EQ? The Hindu. Education Plus 2015 Dec 7; sec.4 (col.1).

2. Sundari SA, Vijayalakshmi, Julie A. Emotional intelligence programme on emotional intelligence among IT professionals at NHON technology private limited, Chennai. TNMC 2015;12-6.

3. Goleman. Working with emotional intelligence. New York: Bantam Books; 1998. p. 9-12.

4. Prevalence of adolescence in the world. [online].[cited 18 May 2013]. Available from: URL:http://web.unpfa.orga/focus/india/face to face/docs/adolescent profile.pdf [accessed on 1/1/16].

5. Maria $\mathrm{C}$, Ferrer S. Influence of emotional intelligence in self concept. International Journal of Learning and Development 2012;2(1):7-13.

6. Psychology of adolescence [online]. Available from: URL:http://psychology about.com [accessed on 1/1/16]. 
7. Whitley-Hunter BL. Validity of transactional analysis and emotional intelligence in training nursing students. Journal of Advanced Medical Education Professional 2014 Oct;2(4):138-45.

8. Pisanos DE. Emotional intelligence: it's more than IQ. Journal of Continuing Education in Nursing 2011 Oct;42(10):439-40.

9. Sharma SK. Text book of nursing research and statistics. New Delhi: Elsevier Publication; 2010.

10. Lyon SR. Tortter F, Holt B, Powell E, Roe A. Emotional intelligence and its role in recruiting nursing students. Nurse Standard 2013 Jan 5-11;27(40):41-6.

11. Senyuva E, Kaya H, Isik B, Bodur G. Relationship between self compassion and emotional intelligence in nursing students. International Journal for Nurse Practice 2014 Dec;20(16):588-96.

12. Allen DE, Ploeg J, Kaa Salainen S. The relationship between emotional intelligence and clinical teaching effectiveness in nursing faculty. Journal of Professional Nurses 2012;28(4): 231-40.

13. Codier E, Odell E. Measured emotional intelligence ability and grade point average in nursing students. Nurses Education Today 2014;34(4):608-12.

14. Brooks, Dubois JH, David. Individual and environmental product of adjustment during the $1^{\text {st }}$ year of college. Journal of College Student Development 1995;36(4):347-60.

15. Fathima AR, Mahlindayu T, Muniruddin O, Nik Nebile RY. Personal, family, academic factors towards emotional intelligence: A case study. International Journal of Applied Psychology 2013,3(1):1-6.

16. Zen-Yin C, Ruth X. Comparing adolescent only children with those who have sibling on academic related outcome and psychological adjustment. [online]. Available from: URL:www.hindewi.com/Journal [accessed on 12/03/2017].

17. The relationship between emotional intelligence and academic stress in students of medical sciences. [online]. [cited 13 Jul 2013]. Available from: URL:https://www.ncbi.hlm.nih.gov/pmc/articles/PMC3778639/\#-ffn-sectitle [accessed on 12/03/2017]. 